\title{
Citizenship and School Library: Simple Educational Experiences for Complex Problems (Portugal)
}

\author{
Liliana Martins Silva \\ liliana.silva@dge.mec.pt \\ School Libraries Network
}

Keywords: citizenship, educational dynamics, school libraries, Portugal.

\begin{abstract}
The School Libraries Network, in Portugal, proposes to reinforce the trend of non-formal and informal education for inclusive citizenship through the realization of educational dynamics, based on real problems that affect the daily life of children and young people. These learning games are accessible, flexible and appealing ways to induce awareness, reflection, dialogue and initiative, on the basis of which it is possible their own transformation and the transformation of the world around them.
\end{abstract}

\section{Introduction}

In Portugal, the School Library Network (SLN) Program was established in 1996 and is coordinated by a central office in the Ministry of Education led by a national coordinator assisted by a small number of technical advisors. At an intermediate level there are about forty regional coordinators who monitor the work of school libraries, ensuring that librarians working in schools understand and implement the central guidelines and providing training and support for teacher librarians to ensure a certain uniformity in the quality of school library performance. There are currently about 2500 school libraries responsible for implementing the SLN Program.

This Program has been developing and growing over these twenty-three years, always seeking appropriate responses to the educational challenges that arise.

Currently, one of these challenges is that of an education for citizenship which, in today's world, is gaining a renewed and increased importance.

The complexity of today's problems, coupled with digital and technological innovations (including biotechnology), is widening and deepening the issues concerning humanity's relationship with itself and with the planet. As a result, in a global governance strategy, States have set themselves seventeen indivisible and universal Sustainable Development Goals, to ensure that all citizens are able to enjoy the benefits of sustainable development, in order to guarantee that "no one will be left behind" (United Nations, 2015).

As an answer to the 2030 Agenda, the United Nations have called for participation and involvement not only of national and local governments, but also of the civil society and children and young people who are recognized, as Oh Joon, the President of the United Nations Economic and Social Council, says, 
"agents of change, no matter the age or means" (United Nations Division for Sustainable Development Goals, 2016).

In order for education to develop in children and young people competences that will enable them to transform these challenges into reality and face the diversity, uncertainty and speed of today's world, it is necessary for educators and teachers, and for teacher librarians in particular, to assume that the purpose of education is the development of the whole person, viewed from a holistic perspective, that is, in all its emotional, cognitive, social and intercultural dimensions, among others.

\section{Framework}

To provide a basis for the education and training of children and young people, the European Commission established, in 2016, A New Skills Agenda for Europe (European Commission, 2016), which has been continuously updated and distinguishes three types of competences:

- DigComp into Action - Get Inspired, Make it Happen (European Comission, 2018a);

- EntreComp: The Entrepreneurship Competence Framework (European Comission, 2018b);

- Key Competences for Lifelong Learning (European Comission, 2018c).

The European Commission has also proposed the reference framework of Competences for Democratic Culture (Council of Europe, 2016) and the Organisation for Economic Co-operation and Development (OECD) has proposed the Programme for International Student Assessment [PISA] 2018 based on Global Competences (OECD, 2018).

In this context, the following documents are proposed in Portugal to guide education and teaching in this country and, in particular, the action of the SLN:

- Inclusive education legal policy (Decree-Law n. 54/ 2018, July 6): promotes the involvement and participation of children and young people in the design and evaluation of their own learning, having led to the regular creation, in schools and in their libraries, of advisory councils, youth assemblies and other types of meetings and spaces for discussion; it also promotes "the exercise of active citizenship, social participation (...) on current issues" (paragraph $\mathrm{d}$ of point 1 of article 19), in the context of which the educational actions are planned and carried out with a connection to the real life of children and young people. In this way those actions acquire meaning for them and have an effective value in the transformation of local contexts.

- Profile of Students Leaving Compulsory Education (Decree-law n. ${ }^{\circ}$ 55/ 2018, July 6): defines the skills that students should achieve by the end of the 12th grade; establishes Citizenship and Development as a compulsory curriculum component, according to the National Strategy for Citizenship Education and ensures the development of essential and flexible learning. It considers that there are ten areas of competence articulated with each other: "Languages and texts; Personal development and autonomy; Information and communication; Wellness, health and environment; Reasoning and problem solving; Aesthetic and artistic sensitivity; Critical thinking and creative thinking; Scientific, technical and technological knowledge; Interpersonal relationship; Body Awareness and Command”.

Although the national guidelines strengthen the convergence of States (convergence is the first IASL Conference's sub-theme), they are very recent and are therefore still being assimilated by those responsible for school libraries and schools. Thus, the answer to the following questions is still being considered: 
- How to make the transition between a rather static curriculum design to a dynamic competences design, according to which we want children and young people to simultaneously develop knowledge, values and attitudes?

- How to think the research model and the selection and content production in a child-centered learning culture that aims to develop global learning skills throughout life?

- What modifications should we introduce to the current forms of communication so that they are used for responsible and ethical sharing of relevant information, for the defence and protection of human rights and for personal and collective enrichment and well-being?

- How to create conditions - in terms of space and resources (human, technological and documentary) - so that the school library is conducive to the development of flexible educational activities and of meaningful and consistent skills based on relevant information? Reader communities, project-based research, inquiry methodology, voluntary service, educational dynamics and gaming are examples of some of these activities.

\section{Citizenship and School Library - Thinking and Taking Action}

Assuming the purpose, established in the Charter on Education for Democratic Citizenship and Human Rights Education (Council of Europe, 2010), of transforming society through education, the SLN proposes to encourage the creation of opportunities that help children and young people to become aware of current problems, discuss them and participate in public space and opinion, as empowered actors responsible for their solution.

In order to achieve this goal, the SLN created an online portal, focused on children and young people and entitled Citizenship and School Library - Thinking and Taking Action, which proposes the realization of educational dynamics, that is, learning games that favour children's willingness to participate or "empowerment", the second IASL Conference's sub-theme. Thus, it is through a non-formal and informal education strategy that it contributes to the protection and promotion of the principles and values of democracy and human rights throughout life and, consequently, to the development of the newly created National Strategy for Citizenship Education in Portugal.

\section{Educational Dynamics}

These educational dynamics are organized in three interdependent dimensions that contribute to the internalization of behaviours and individual transformation, on the basis of which the transformation of society is possible:

Testimonies: Accounts of personal experiences of struggle for a cause, resulting from the individual awareness and position (decision) regarding a critical situation of society; they favour the clarification, involvement and dialogue in the community, constituting a strategy of inner growth and of combating social indifference and passivity. Because testimonies can express opinions and feelings instead of knowledge and facts, and because there is currently a tendency in the media culture to attract the attention of society through the spectacle of the self itself, it is fundamental to evaluate the credibility (character and authority) of the source or person who witnesses and the logical basis of his/ her argumentation.

Some examples of testimonies: cases, critical incidents and examples; photovoices; TED talks; opinion articles, interviews, reports, documentaries and other media actions.

Discussions: This educational dynamic aims, in an intentional and radical way, the clarification of the testimonies. It is an opportunity to analyse and express one's own points of view, considering the points of view of others; to exert influence and leadership with the other elements of the group and to collaborate 
and build consensus. Arguing is also a human right enshrined in the Convention on the Rights of the Child (points 1 and 2 of article 12 - United Nations, 1989). For the discussion to build an objective conclusion that represents the main points of view, it is necessary to guarantee a sufficient critical mass, involving a significant number of elements, but not so many that would inhibit the participation of all. The quality of the discussion also depends on the prior research work carried out by the participants and on the fact that, during the session, they respect the topics and times assigned to each one and establish a respectful and constructive communication.

Some examples: dialogues, debates, questions, dilemmas; role playings, courts...; assemblies, forums, councils of representatives, congresses, summits (web summits), open classes, meetings...; reader communities, gatherings in the neighbourhood, cafes, clubs, circles or idea laboratories (think tanks....); speed meetings, elevator pitches...

Socio-political activism: It consists in intervening with the purpose of transforming the community. In democracy it is essential that activism results from a previous work of awareness and critical justification of the action to be implemented, which is why the exercise of this educational dynamic intersects with the dynamics of testimonies and discussions.

Some examples: solidarity and good cause activities - campaigns (garbage collecting, blood donation...), marathons (of cards, programming, cartoons...), solidarity sports events; artistic events (collective exhibitions, murals, art installations, think tank photos, ethnic music show, commented songs, flash movs, flash mobs...); petitions, boycotts, demonstrations; actions of preservation and dissemination of heritage (tourist itinerary, virtual museum, environmental atlas...); associations...

Our educational dynamics, in the citizenship area, have a simple nature, that is, truthful (according to reality and its knowledge). Therefore they focus on themes such as:

- Well-being and care related with oneself and others;

- Responsible and cautious environmental use;

- Democracy in the era of the fragmentation of powers;

- The place of minorities in the public space and opinion;

- Freedom versus algorithms and artificial intelligence.

\section{Good Experiences - Examples}

In December 2018, the SLN elaborated a report about the work done with the school libraries in the citizenship area. It was based on the results of a survey implemented among regional coordinators of school libraries.

We have chosen two main trends in the action of the SLN that we justify with examples in which children and young people are the protagonists:

1. There was a concern that the activities involved children and young people of all ages, families, partners and, in general, the community, putting institutions and people in dialogue and working together.

\section{Examples of actions involving local partners:}

- Sustainability kits - environmental education project (climate, energy efficiency, sustainable mobility, consumption, circular economy, ocean and natural heritage) with Arrábida Energy and Environment Agency - School Group Lima de Freitas (Setúbal); 
- All rights for all: conference followed by a discussion with the leaders of the International Organization for Migration, Global Platform Association to Support Syrian Students, United Nations Population Fund, Crowned Hearts Association, UNICEF, Chocolate Stage Theatre Company - School Group Canas de Senhorim (Nelas)

- Examples of school library actions involving international partners:

- Equi X-Nonviolent Masculinity Building Program: a pilot project of the European Commission through the European Union's Rights, Equality and Citizenship Programs 2014-2020 - School Group Pombal (Pombal);

- Books that make us grow: 17 books, one per goal (Sustainable Development Goals); each book has a story and an activity on a development goal. This is an activity with the UNESCO Chair in Biodiversity Safeguard for Sustainable Development at the University of Coimbra and Center for Functional Ecology - School Group Aurélia de Sousa (Porto).

- There was also an interest that the activities should articulate levels of education and teaching within the same school and school cluster and with schools and clusters from different national and international geographies (Erasmus ${ }^{+}$programme) - examples:

- Yourope: You in Europe - Europe's past (Second World War and its reflection nowadays), present and future (human rights and refugees) - School Group Colmeias (Leiria);

- Fortnight of Activism for Gender Equality: All Equal, All Different - School Group Carolina Michaëlis (Porto).

2. It was paid special attention to the national curriculum contents that introduced this year the National Strategy for Citizenship Education connecting curriculum areas and subjects and combining curriculum development with the informal and non-formal learning. The important thing is that children and young people become aware and understand the effective unity of knowledge, their social purpose and the value of keeping on learning.

- Examples of actions with the school library that promote horizontal and vertical curriculum articulation:

- A country of my own - students create their own country, defining forms and systems of government, sovereignty bodies, flag and other national symbols, institutions, development goals and rights -School Group Pombal (Pombal).

- One word, one right, one image: collective panel on human rights associated with culture and art, exhibited December 10, International Human Rights Day -School Group Coimbra Sul (Coimbra).

- Examples of activities that promote the pleasure of reading, as well as training and deepening reading skills:

- Do criminal suspects have the same rights as ordinary citizens? Discussion with the participation of Public Security Police, a journalist and an Amnesty International lawyer -School Group Manuel Teixeira Gomes (Portimão);

- Women and men's "presence" on the written press: daily press analysis for a reflection about gender inequality in positions of power and decision-making - School Group José Afonso (Moita).

International Association of School Librarianship

https://iasl-online.org 
- Digital wall with poetry from 15 different languages, followed by a soiree open to the community School Group Cidadela (Cascais).

- Meetings with writers from different nationalities and other inspiring people:

- Meet a Global Volunteer: neighbourhood meeting with a native American that belongs to ONG Global Volunteers - School Group nr. 2 of Serpa;

- Talking with a blind person: about the adaptations that blind people need to make in their everyday life and how their communication code works -School Group D. João I (Moita).

Although we do not yet have specific data on the participation of children and young people and school communities in these activities, we observed that the activities carried out in the citizenship area are one of the rare cases in which they are in greater number than planned. This confirms the idea that the work done for the common good has a multiplying effect (it is contagious).

The SLN webpage, Citizenship and School Library - Thinking and Taking Action also has a tab, entitled $\underline{\text { School Notes, }}$, where school libraries share activities that they perform in the citizenship area so that we can learn from one another and share good ideas.

\section{Conclusion}

It was a collective process that brought us to the complexity of current problems. Therefore, it is together that we must make transformations in the sense that we must follow a different path, compatible with Earth's limits and needs and of all those who inhabit it.

This is the path of "inclusive citizenship" recommended by the United Nations Secretary-General, António Guterres (Almeida, 2019) and by the main european and national documents that guide the vision and mission of the SLN in Portugal.

\section{REFERENCES}

Almeida, J. (2019, May 29). Guterres considera que o maior desafio da inovação é a cidadania inclusiva. O Jornal Económico. Retrieved from:https://jornaleconomico.sapo.pt/noti cias/guterres-considera-que-o-maior-desafio-da-inovacao-e-a-cidadania-inclusiva-450127

Council of Europe. (2010, May 11). Charter on Education for Democratic Citizenship and Human Rights Education. Retrieved from: https:/www.coe.int/en/web/edc/charter-oneducation-for-democratic-citizenship-and-human-rights-education

Council of Europe. (2016). Competences for Democratic Culture - Living Together as Equals in Culturally Diverse Democratic Societies. Retrieved from: https://www.coe.int/en/web/education/competences-for-democratic-culture.

European Commission. (2016, June 10). A New Skills Agenda for Europe - Working

Together to Strengthen Human Capital, Employability and Competitiveness. Retrieved from: https://eur-lex.europa.eu/legal-content/en/TXT/?uri=CELEX\%3A52016DC0381

European Commission. (2018a). DigComp into Action - Get Inspired, Make it Happen. Retrieved from: http://publications.jrc.ec.europa.eu/repository/b itstream/JRC1106 24/dc_guide_may18.pdf. 
European Commission. (2018b). EntreComp: The Entrepreneurship Competence

Framework. Retrieved from: https://ec.europa.eu/jrc/en/publication/eur-scientific-and-techni cal-research-reports/entrecomp-action-get-inspired-make-it-happen-user-guide-european-entrepr eneurship-competence.

European Comission. (2018c). Key Competences for Lifelong Learning. Retrieved from: https://eur-lex.europa.eu/legal-content/EN/TXT/?uri=CELEX:52018DC0024.

Government of Portugal. (2017). National Strategy for Citizenship Education. Retrieved from: http://www.dge.mec.pt/sites/default/files/Projetos_Curriculares/Apren dizagens_Essenciais/estrategia_cidadania_original.pdf.

Government of Portugal. (2018, July 6a). Decree-law n. 54/ 2018, July 6. Retrieved from: https://dre.pt/web/guest/home/-/dre/115652961/details/maximized?res=en

Government of Portugal. (2018, July 6b). Decree-law n. 55/ 2018. Retrieved from: https://dre.pt/web/guest/home/-/dre/115652962/details/maximized?res=en

Organisation for Economic Co-operation and Development. (2018). Global Competence. Retrieved from: https://www.oecd.org/pisa/pisa-2018-global-competence.htm

United Nations. (1989, November 20). Convention on the Rights of the Child. Retrieved from: https://www.ohchr.org/documents/professionalinterest/crc.pdf

United Nations. (2015). Transforming our World: the 2030 Agenda for Sustainable Development. Retrieved from: https://sustainabledevelopment.un.org/content/docu ments/21252030\%20Agenda \%20for\%20Sustainable\%20Development\%20web.pdf.

United Nations Division for Sustainable Development Goals. (2016, February 2). ECOSOC Youth Forum. Retrieved from: https://sustainabledevelopment.un.org/index.php?page=view\&type $=30022 \& n r=222 \& m e n u=3170$.

\section{Biographical Note}

Liliana Martins Silva works in School Library Network Program as school library adviser and trainer in the area of citizenship education (Ministry of Education).

Presenter name, affiliation, city, country, email:

Liliana Martins Silva, School Libraries Network (SLN), Lisbon, Portugal, liliana.silva@dge.mec.pt 